\title{
Tracking the Impact of COVID-19 to United States Airline Industry: A Case Study
}

\section{Jameel Mohammed Ahmed and Shanavas Moosafintavida*}

\author{
Azteca University, Mexico, North America
}

*Corresponding author: shanavas.musafi@gmail.com

\begin{abstract}
COVID-19 is having a significant impact on the wider global transport framework. This article draws attention to the analysis of the impact of the travel restrictions imposed in the context of COVID-19 to the U.S Airlines. As per the Analysts, major and more profound misfortunes are expected for the U.S Airlines in the coming months. A recuperation is muddled as instances of the virus and related fatalities keep on climbing. Delta and United Airlines have rumoured their $1^{\text {st }}$ and $2^{\text {nd }}$ quarterly losses in additional than 5 years. Their competitors are expected to unharness dismal leads to the approaching weeks. succeeding few months look even additional painful for the world because the coronavirus pandemic saps travelling demand throughout what is commonly the foremost profitable time of year (CNBC News 2020). Before the pandemic hit, airlines struggled to spice up revenue, as they older increasing volumes of traveller and merchandise traffic. Over the past 5 years, earnings for the world airlines business grew at a less-than-desirable pace, because of unstable fuel costs, increasing competition, the prevalence of inexpensive fare, and call-in world trade. celebrated for prime fastened operational prices, airlines have usually two-faced a spread of great market challenges. Therefore, this aviation market setting is filled with reasons for concern, however, the associate ultimate recovery is anticipated for the U.S airline business. While COVID-19 continues to endanger many various sectors of the economy, "no trade has seen a larger impact than airlines," in step with the marketing research firm Global Data (Sarah, 2020).
\end{abstract}

Keywords: Aviation, Air Transport, Covid-19, Virus, Fatalities, Economy.

The COVID-19 pandemic has had a major impact on the aviation business in the United States of America because of travel restrictions and a slump in demand among travellers. Significant drops How to cite this article: Ahmed, J.M. and Moosafintavida, S. (2021). Tracking the Impact of COVID-19 to United States Airline Industry: A Case Study. Learning Community, 12(01): 01-12. 
in passenger numbers have resulted in flights being off or planes flying empty between airports, that successively massively reduced revenues for airlines and compelled several airlines to put off staff or declare bankruptcy. In 2018, The United States of America has the biggest air market of any single country, with nearly 889 million passengers being transported and there have been fifty-eight airways with inside the United States, of which 17 are categorized as primary vendors with over a thousand million U.S. Dollar in revenue (Mazareanu, 2020). Broadly, the airways with inside the U.S. may be divided into 3 most important categories: full-carrier legacy vendors, low-price vendors, and local vendors. Legacy vendors are the one's airways with setting up interstate routes on the time of the airline enterprise deregulation in 1978. In a long time since, the 3 massive legacy vendors - Delta, American and United - have together merged with or received the bulk of vendors present before deregulation. Alaska Airlines and Hawaiian Airlines are the most effective different legacy vendors nevertheless in operation. The legacy vendors currently account for simply over $1 / 2$ of the home market and the bulk of intercontinental flights (Revfine, 2020).

The U.S. Passenger airlines area unit several the biggest within the world, with Delta and American Airlines being the world's largest. Several factors justify the leading position of the U.S. aviation market that includes the country's size, in terms of Geography, Population and the economy. The shortage of a high-speed rail network and other factors produce a large demand for domestic flights, with this usually being the sole possible possibility for long-distance visits. It stands as a hub for intercontinental travel. Not solely do touristry and business produce high demand for intercontinental flights, but the U.S. is usually a stopover destination for flights to different countries within the region (Tracy and Sanjana, 2020).

Thus, the pandemic has brought the air transportation area in the United States of America to a halt surprisingly fast, with request plunging for both homegrown and global travel. As COVID-19 spread across the globe, organizations and schools moved online to diminish infection presentation, joblessness rates soar, travel limitations were executed, and the profoundly infectious nature of COVID-19 made individuals uncomfortable with voyaging (Bureau of Labor Statistics, 2020). On March 27, 2020, The U.S. government mediated, and the CARES (Coronavirus Aid, Relief, and Economic Security) Act was endorsed into law and gave $\$ 50$ billion in monetary help to traveller transporters and $\$ 8$ billion to freight transporters through a blend of advances, advance certifications, and finance uphold (Congress, 2020). Nothing stops all 10 of the biggest US. Passenger carriers along with 340 Passenger carriers from signing an agreement to receive monetary help through the CARES Act (U.S. DOT, 2020). Consequently, the air transporters who got monetary help should keep up specific prerequisites. They are denied from lessening the compensation paces of representatives or compulsory furloughing labourers, and a portion of these air transporters are additionally needed to keep a base degree of service to homegrown urban areas served pre-pandemic until September 30, 2020 (U.S. DOT, 2020a).

This is not the principal occasion to cause a significant decline in air travel. For instance, during the Great Recession of 2008, carriers modified their operational methodologies and organizations postRecession (Atallah, 2018). Apart From the 2008 Great Recession, the 9/11 attacks in 2001 and SARS in 2003 additionally hastened a stun to the air framework. These earlier occasions of vulnerability can 
give bits of knowledge into the recuperation from future stun occasions in the aircraft business. The past vulnerability stuns to conjecture COVID-19 related abatements in U.S. aircraft business and assessed a post-pandemic decay of $7 \%$ of the carrier labour force (or 32,000 workers) (Sobieralski, 2020). Even though there stays a lot of vulnerability about how long the COVID-19 pandemic will continue and what amount of time it will require for air transportation to recuperate, numerous specialists accept the effects will be a long haul. As per industry pioneers, recuperation is required to be in any event 3 to 6 years (Josephs, 2020). What is obvious from past slumps is that interest for air travel will ultimately skip back. Be that as it may, the business will probably rise out of this emergency altogether adjusted. During times of air travel decline, flight tasks and air terminal assistance levels are zones of worry, as aircrafts face decreased interest which impacts their organization arranging techniques and the business sectors they decide to fly (Spitz et al. 2015).

The motivation behind this article is to audit COVID-19's sway on Domestic and Commercial Air operations services help during the months quickly following COVID-19. The pandemic's effect on the country's air travel and operations is dissected first. At that point, Airline reactions to the pandemic are investigated by examining how airline companies have changed their Business strategy during pandemic days. Here, the goal is to evaluate how aircrafts' reactions to the pandemic impacted services.

\section{Airline Industry Overview}

The worldwide carrier industry offers support to practically every side of the globe and has been a necessary piece of the production of a worldwide economy. The carrier business itself is a significant financial power, both regarding its own activities and its effects on related ventures. The worldwide carrier industry managed major mechanical advancements, for example, the presentation of jet planes for Commercial use during the 1950s, trailed by the improvement of wide-body "large planes" during the 1970s. Simultaneously, aircraft were vigorously controlled all through the world, establishing a climate in which innovative advances and government strategy outweighed productivity and rivalry. It has just been in the period since the monetary liberation of carriers in the United States in 1978 that inquiries of cost proficiency, working productivity and serious conduct have become the predominant issues confronting aircraft the executives. With the US driving the way, aircraft liberation or if nothing else "progression" has now spread to a large part of the industrialized world, influencing both homegrown air travel inside every nation and, maybe more significantly, the proceeding with the advancement of a profoundly serious global carrier industry. Today, the worldwide carrier industry comprises of more than 2000 aircraft working more than 23,000 aeroplanes, offering support to more than 3700 air terminals. In 2006, the world's aircraft flew just about 28 million planned flight takeoffs and continued 2 billion travelers (International Air Transport Association (IATA)). The development of world air travel has found the middle value of roughly $5 \%$ every year in recent years, with significant yearly varieties due both to changing financial conditions and contrasts in monetary development in various areas of the world. Truly, the yearly development in air travel has been about double the yearly development in GDP. Indeed, even with generally traditionalist assumptions for financial development throughout the 
following 10-15 years, a proceeded with 4-5\% yearly development in worldwide air travel will prompt a multiplying of absolute air travel during this period.

In the US aviation industry, around 100 certificated traveller aircraft work more than 11 million flight takeoffs for each year and persist 33\% of the world's absolute air traffic - US carriers enplaned 745 million travellers in 2006. US carriers detailed over $\$ 160$ billion in all-out incomes, with around 545,000 workers and more than 8,000 aeroplanes working 31,000 flights for every day (Air Transport Association of America (ATA), 2007). The monetary effects of the carrier business range from its immediate consequences for aircraft work, organization productivity and total assets to the less immediate yet significant impacts on the aeroplane fabricating industry, air terminals, and the travel industry enterprises, also the financial effect on basically every other industry that the capacity to go via air creates. Business flying contributes 8 per cent of the US Gross Domestic Product, as per late gauges (ATA, 2014). The monetary significance of the Airline industry and, thus, its repercussions for aeroplane makers, makes the unpredictability of aircraft benefits and their reliance on great financial conditions a genuine worry for the two ventures. This worry has developed drastically since carrier liberation, as steady benefits, as well as government help, were the standard as opposed to the exemption for most worldwide aircraft preceding the 1980s. The all-out net benefits of world aircraft have indicated gigantic instability in recent years.

After the world aircraft industry posted 4 sequential long periods of misfortunes totalling over $\$ 22$ billion from 1990 to 1993, because of the Gulf War and ensuing monetary downturn, it got back to record benefit in the last part of the 1990s, with complete net benefits in the overabundance of $\$ 25$ billion being accounted for by world carriers from 1995 to 1999 (Troy, 2020). Significantly more emotional was the business' dive into record working misfortunes and a monetary emergency somewhere in the range of 2000 and 2005, with total overall deficits of $\$ 40$ billion. Since 2008, the aircraft have charged subordinate expenses for administrations that were prior included for the airfare. In the wake of recording 26.1 billion U.S. dollars total deficit in 2008, the aircraft business progressively defeated to net benefit till 2019, recording 26.4 billion U.S. dollars. In 2020, due to the COVID-19-episode, business aircraft are assessed to have net benefit misfortunes of 118.5 billion U.S. dollars (Mazareanu, 2020). Carriers are important for a bigger financial area that has been fundamentally affected by COVID-19, and it is accepted that any conversation of government help ought to consider transportation more comprehensively. Carrier request is not relied upon to completely recuperate for a couple of years. Consequently, aircraft ought to scale back, and we are seeing this happen now.

\section{Tracking the Impact of COVID-19 to us Airline Industry}

United States Airlines has experienced diverse major impacts tallying major financial hardship from capacity diminishes of flights and is standing up to criticism for how the aircraft is responding. This joins assertions of buying offers back in a try to drive up the fetched. It consolidates Extreme flight diminishes, demands for talking about travel has dropped extraordinarily, so the carrier has been obliged to suspend flights due to travel controls and cut flights which are not profitable. It costs a 
portion of money for the Airline companies to keep one operational and they burn through cash at a fast rate. Usually, a particular issue at the appear as there's right now outstandingly little cash coming in. American Aircrafts has seen its share costs decrease radically since COVID-19 started showing up grave impacts inside the United States of America (Global Data, 2020).

Key Impacts (Airlines for America, 2020)

U.S. airline passenger numbers fell 57\% from 2019 levels Domestic air travel fell 56\% and international air travel fell $66 \%$.

Departures of passenger airlines from the United States were 39\% below the 2019 level. The number of flights on domestic flights fell by $38 \%$, on international flights - by $45 \%$.

Domestic freight rates averaged 61\% for the most recent week and 88\% for the same week in 2019 .

The average domestic flight in the United States is 74, and the average domestic flight is about 99 passengers per departure in 2019.

Before December 2020 vs. the end of 2019, there has been no significant reduction in the change in airport capacity in December 2020, the year of traffic and capacity in the entire system.

The amount of Transportation Security Administration (TSA) checkpoints was 51\% below the 2019 level.

At US airports in December, the largest reduction in passenger traffic occurred in Vermont and was the smallest in the United States. The rate of change in passenger capacity by US states is December 2020 compared to December 2019.

Excluding test-based quarantine for Hawaii significantly increased air travel by $94 \%$ in the first half of October compared to 2019.

US International Air Flights down 79\%, Non-US Citizens arrivals put down $84 \%$ and the exit of US citizens fell $74 \%$.

Of the 20 largest pairs in the United States and countries in October 2019, 14 year-over-year declines have crossed $90 \%$ between the United States and Mexico and between the United States and the Dominican Republic.

Aircraft are Adapting by Taking on Billions in Obligation Up 63\% From the year 2019 to 2020. Net Interest Cost Multiplied From 2019 to 2020 and Will Approach \$14.7B in 2021-2023.

In October 2020, Mexico was a clear leader in US international air travel. Latin American and Caribbean airports are the most popular foreign gateways to/from the United States. 
Corporate air travel still survives the steep fall that began in March. There are many ways to "travel", some of which are less vulnerable to alternatives than others. The rapid decline in demand, especially business travel, overwhelming airline profits.

The pandemic has had a significant impact on voluntary job cuts, retirement, job changes, dismissal of employers and other factors in the US. Airlines.

From March to October 2020, U.S. Traveler Aircraft Work Fell by 92,000 FTEs (20\%) Over the Past Two Decades, Work Development Has Closely Followed the Industry's Financial Health.

One-Fourth of the U.S. Passenger Carrier Fleet Was Inert at the End of 2020 Roughly 400 Airplane Were For all time Retired in 2020.

Domestic US air cargo demand outstrips international trade with Asia and contributes to the recovery of US international air cargo (Airlines for America, 2020).

Additionally, American Airlines has taken several self-help actions to reduce cash burns with historic reductions in capacity, parking, and/or the abolition of older aircraft (possibly all types of fleets). Used an airliner on a berry or berry main cabin cargo only mission. Reduce executive compensation and implement voluntary leave and early retirement programs, freeze employment and unnecessary expenses (e.g., employee travel, consultants, events, marketing, training), settling in airport facilities (e.g., lobby) Print integration. Shutter Lounge; Suspension of real estate projects Simplification of internal products (e.g., food and beverages. Negotiation with suppliers: associated credit cards, airports (i.e., interest-free rental deferral), regional partner airlines (i.e., lockdown time) Shortening), fuel suppliers, catering companies, etc. Fundraise: Temporary capital repayment programs, such as borrowing funds with secured or unsecured loans and/or selling stocks through sale/mortgages for aircraft/engines / other assets, share buybacks and future dividend payments Stop (Globle Newswire, 2020).

Moreover, The United States Department of the Treasury issued a COVID-19 aid package to provide crucial support for all American people and further strengthens America's economic recovery. The aid bills provide quick and direct financial assistance to American workers, families and small businesses and protect jobs for American industries (U.S. Department of the Treasury, 2020). The CARES Act payroll support program kept the airline's employees at work but left a deficit of $\$ 3.7$ billion. PSP enables airlines to maintain full salaries and accelerate US economic recovery. CARES Act PSP was a pass-through to carrier labourers -a combination of awards and advances (to be reimbursed with intrigued to U.S. Treasury) - for the period April $1^{\text {st }}$ to Sept. 30, 2020. For the nine biggest traveller carriers after deducting the sum repayable to U.S. Treasury, PSP grants secured fair $82 \%$ of finance costs, clearing out them with a $\$ 3.7 \mathrm{~B}$ shortage for the appropriate six-month period. Financial counselling firm Compass Lexecon assessed that, by keeping their labourers utilized through Sept. 30, PSP grants to U.S. traveller carriers spared U.S. Treasury \$6.0-10.2B and state treasuries \$3.2-5.5B. U.S. Passenger Carriers Have Drawn $\sim \$ 19$ Billion in CARES Act Credits Reserves Expecting to Assist Carriers Proceed Operations Whereas Request Remains Impeded. The credit proceeds will be utilized to supply liquidity to proceed 
the Company's operations... Treasury will get warrants to purchase common stock break even with to $10 \%$ of the full advance sum drawn (Congressional Research Service, 2020).

\section{Future Strategy for Airline Industry Post COVID-19}

How can the future of the airline industry survive beneath the current dull request and lessened income situations? What long-standing Time of Air Travel Looks Like As antibody dissemination starts, here is what to anticipate in 2021 and past.

Long-haul flights will see unused innovations: From virus-sniffing pooches in air terminals to modern apps that prepare travellers' COVID-19 data and contact-tracing from carriers, the discuss travel industry is getting inventive in arrange to restart long-haul flights. Delta, for one, is set to restart flights to Europe with a modern test regimen, whereas modern apps will make immunization status and the test comes about simpler for border authorities to peruse (Blane, 2020).

Trade travel will get a reboot: One of the foremost vital parts of airlines' recuperations will be winning back commerce voyagers. But this profitable segment of travelers won't settle for the same ancient premium cabin. Sometime recently they get back onto planes, trade fliers need to see major alterations like seats that are roomier and more private, passage classes with included advantages, and indulgent loyalty program policies-to title some (Jessica, 2020).

Immunizations are as of now making a distinction: An immunization is on the skyline, and voyagers are as of now feeling more hopeful around flying another year: Flight look location Skyscanner detailed that U.S. bookings for economy round-trip flights bounced up 9 per cent on the heels of the primary positive immunization news. Aircraft CEOs, counting those at Qantas Aviation routes and Delta, have as of now indicated that they will before long require their travellers to be vaccinated sometime recently flying (Jessica, 2020).

Modern planes will alter the carrier experience: As the post-pandemic recuperation begins to require shape, specialists say that the set-up slant of carriers eschewing larger double-decker planes, just like the Boeing 747 and Airbus A380, will quicken. Instep, carriers are selecting for more agile and proficient jets-and indeed contributing to a few cutting-edge plans like a "blended wing" aeroplane. Littler planes will not cruel less consolation: Anticipate seeing more extensive seats, bigger windows that are able to dim, and more open overhead canisters (Barbara, 2020).

Family travellers will decide airlines' most current destinations: Among the few dependable discuss travellers this year? Diaspora populaces going to relatives. What began as a request for uncommonly facilitated repatriation flights for those stranded overseas during the spreading out COVID-19 emergency got to be the motivation for profitable unused universal courses. Presently, carriers around the globe are forming modern course dispatches around this statistic: places like New Delhi, Accra, Brisbane, Bangalore, and Lagos are fair a couple of the goal's carriers have included to their maps so distant (Kristin, 2020). 
Booking will stay flexible: Passengers have been managed more adaptability amid the crisis-and they will be hated to provide it up down the line. Luckily, U.S. aircraft appear to have as of now recognized this truth and have gone to work nixing badly designed alter and cancellation expenses. Flying standby on the same day and putting visit flier miles back into devotion accounts are getting to be free benefits, as well. But the jury is still out on whether situate determination or things expenses will see the chopping square (Jessica, 2020).

Medical care will be accessible at the airport: While COVID-19 testing in aeroplane terminals is getting to be increasingly omnipresent, specialists accept that the slant of therapeutic clinics at the aeroplane terminal will outlive the infection. "For universal travel within the future after you have to behave your immunizations and take meds in case you're going on safari in Africa, [fliers will] be able to come to the air terminal and have that as the portion of your schedule," says Doug Saltzman, CEO of aeroplane terminal spa chain XpresSpa, which turned to advertise COVID-19 screenings and counteracting agent tests over the summer. "It's truly a totally lost category in air terminals. We think we are at the cutting edge of making an entirety modern industry of travel wellbeing and wellness (Jessica, 2020).”

\section{Survival and Restoration of U.S. Airline Industry Post COVID-19}

US Airlines industry have battled with challenges around fuel taken a toll and supporting, ideal stack figure, renting fetched, fleet support took a toll and adequacy of loyalty programs. This emergency has made a window to reimagine ways to counter long-standing challenges, which have quadrupled due to the COVID-19 impact. While there is a prompt necessity of cutting costs and minimizing misfortunes, there are more challenges to be anticipated as typical operations start. Carriers can begin evaluating the low hanging ones for remedial measures (Thomas, 2020).

Analytics for appraisal and expectation: Prescient Analytics can help evaluate brought about misfortunes and frequencies at which flights can be worked to support cash saves amid misfortunes, and measures to bring down misfortunes in operational routes.

Customer care change: Aircraft ought to guarantee self-service apparatuses and mechanization for straightforward client enquiries through chatbots. This will help lower costs, empower speedier reactions, and make way better client experience.

Demand era: Through client estimation examination and following of client certainty markers, carriers can empower proactive offers and rebates, for the occasion, personalized offers can be made to future booking cancellations. With such activities, aircraft will be able to fortify request and increment reservations.

Contracting \& training workforce: Due to mass lay-offs amid COVID-19, carriers will have to be contract modern staff on a fast-track premise once operations are back to normal to manage with the request. Preparing would have to be compelled to be executed on fast-paced models. 
Standardizing different operations: Decentralized operations, dissimilar forms at outstations, shifted cycle times for handling information ought to be standardized. This would empower shortening of recuperation time, and quick and simple to execute trade coherence forms.

Within the close future, we may experience new trade models within the aircraft industry and see air terminals prepared with contact-less check-in. The modern ordinary would be more feasible and selfservice-enabled with the essential part played by digitization and mechanization. The COVID-19 crisis has too raised the significance of e-commerce within the US airline industry, be that as it may, it's once more an address of how before long carriers can adjust and change client touchpoints.

\section{CONCLUSION}

The unsettling influences caused by the COVID-19 far-reaching might impact the US airline industry for much longer than the length of the emergency. Hazard revolution and self-imposed social isolating can alter current designs in flying ask and client choices. A conceivable money related hush can encourage complicate the ask and supply of flying organizations, as well as theory and advancement inside the portion. Many aircraft, plane terminals, and other aviation-related chairmen have lost a basic parcel of their in-come since mid-March 2020, raising stresses around their money related stability and their capacity to recover their organizations. Various such administrators will conceivably require facilitate or indirect government support, which can misshape the competition scene at family and worldwide levels.

After 9/11 and the Global Financial Emergency, it took more than seven years for air-travel demand to recuperate traveller volumes from the Budgetary Crisis/Oil Spike. Likewise, the COVID-19 Pandemic will take more duration for the US airline industry to see a return to 2019 Traveler Volumes before 2023-2024. To advance an economical direction for the US airline industry, government approaches ought to organize sector-wide measures and competition. In specific, they require to strike the adjust between the require for back and the hazard of mutilating competition. In occasions where firm-specific bolster measures are fundamental or have been actualized as of now, this ought to not tilt the playing field with other firms within the flying industry. Conclusion of the will be sprier, customer-centric, and green when the COVID-19 crisis-hit US airline industry, they had to reply quickly to compel the hurt. The coming months will be fundamental for survival.

In the short term, airlines focus on ramping down operations, cutting variable and fixed costs, securing liquidity, and taking care of their employees and customers. In the first step, airlines stopped operations on routes with a negative contribution to reducing variable costs. Many have also put their crews and other operations staff on unpaid or government-supported leave. To quickly tackle semi-fixed external, spend, airlines can use digital supplier days to adjust volumes, prices, and flexibility schemes to the new reality. However, they will need to strike a balance between optimizing costs and ensuring the survival of system-critical partners, such as ground handlers and caterers. Therefore, the focus of supplier renegotiations should be on flexibility and not purely on costs. 


\section{REFERENCES}

1. Air Transport Association of America (ATA), 2007 Economic Report, www.airlines.org.

2. Air Transport Association of America (ATA), Statement on the State of the Airline Industry, Statement for the Record of the Sub-committee on Aviation, Transportation and Infrastructure Committee, US House of Representatives, June 2004.

3. Airlines for America. 2020. Impact of COVID-19: Data Updates, Available at: https://www.airlines.org/wp-content/ uploads/2020/03/A4A-COVID-Impact-Updates-38.pdf (Accessed: $5^{\text {th }}$ January 2021).

4. Atallah, S., Hotle, S.L. and Mumbower, S. 2018. The evolution of low-cost Carrier operational strategies pre- and post-recession. J. Air Trans. Manage., 73: 87-94.

5. Barbara, P. 2020. These New Planes Could Change the Way You Travel, Available at: https://www.cntraveler.com/ story/new-planes-that-will-change-the-way-you-travel (Accessed: $4^{\text {th }}$ January 2021).

6. Blane, B. 2020. How Airlines Are Trying to Get Passengers Back on Long-Haul Flights, Available at: https://www. cntraveler.com/story/how-airlines-are-trying-to-get-passengers-back-on-long-haul-flights (Accessed: $3^{\text {rd }}$ January 2021).

7. Bureau of Labor Statistics, 2020. Bureau of Labor Statistics, 2020. The Employment Situation - April 2020. U.S. Department of Labor. https://www.bls.gov/news.release/pdf/empsit.pdf (Accessed 20.05.31).

8. CNBC News. 2020. 'US airlines are losing money for the first time in years as coronavirus ends travel boom', CNBC, 23 04, p. https://www.cnbc.com/2020/04/23/coronavirus-us-airlines-set-to-report-their-first-losses-in-yearsas-travel-demand-falls.html.

9. Congress, 2020. U.S. Congress (2020) H.R.748 - CARES Act. https://www.congress.gov/bill/116th-congress/ house-bill/748 (Accessed 20.05.31).

10. Congressional Research Service, 2020. CARES Act Payroll Support to Air Carriers and Contractors, Available at: https://crsreports.congress.gov/product/pdf/IN/IN11482\#: :text=According\%20to\%20the\%20CARES\%20 Act,payments\%20through\%20September\%2030\%2C\%202021\%2C (Accessed: $3^{\text {rd }}$ January 2021).

11. Global Data (2020) Case Study: The impact of COVID-19 on American Airlines, Available at:https://store.globaldata. com/report/gdtt0354mi--case-study-the-impact-of-covid-19-on-american-airlines/\#tab-table-of-contents (Accessed: $2^{\text {nd }}$ September 2020).

12. Globle Newswire. 2020. American Airlines Reports Third-Quarter 2020 Financial Results, Available at: https:// www.globenewswire.com/news- release/2020/10/22/2112668/0/en/American-Airlines-Reports-Third-Quarter-2020Financial-Results.html (Accessed: $2^{\text {nd }}$ January 2021).

13. International Air Transport Association (IATA), Fact Sheet: World Industry Statistics, www.iata.org.

14. Jessica, P. 2020. 5 Early Indicators of the COVID-19 Vaccine's Impact on Air Travel, Available at: https://www. cntraveler.com/story/5-early-indicators-of-the-covid-19-vaccines-impact-on-air-travel (Accessed: $4^{\text {th }}$ January 2021).

15. Jessica, P. 2020. Business Travelers Want to See Major Changes From Airlines, Available at: https://www.cntraveler. com/story/business-travelers-want-to-see-major-changes-from-airlines (Accessed: $4^{\text {th }}$ January 2021).

16. Jessica, P. 2020. From Manicures to COVID-19 Tests: How an Airport Spa Brand Pivoted During the Pandemic, Available at: https://www.cntraveler.com/story/how-an-airport-spa-brand-pivoted-during-the-pandemic (Accessed: $5^{\text {th }}$ January 2021). 
17. Jessica, P. 2020. U.S. Airlines Get Rid of Change Fees on International Flights, Available at: https://www.cntraveler. com/story/american-airlines-gets-rid-of-change-fees-on-international-flights (Accessed: $5^{\text {th }}$ January 2021).

18. Josephs, L. 2020. Airlines not happy with Boeing CEO after he said one of them would 'most likely' fold. NBC News. https://www.nbcnews.com/business/business-news/airlines-not-happy-boeing-ceo-after-he-said-onethem-n1207211 (Accessed 20.05.31).

19. Kristin, B. 2020. Airlines Are Picking Routes Based on Family Travel Patterns, Available at: https://www.cntraveler. com/story/airlines-are-picking-routes-based-on-family-travel-patterns (Accessed: $5^{\text {th }}$ January 2021).

20. Mazareanu, E. 2020. Net profit of commercial airlines worldwide from 2006 to 2021(in billion U.S. dollars), Available at: https://www.statista.com/statistics/232513/net-profit-of-commercial-airlines-worldwide/ (Accessed: $30^{\text {th }}$ November 2020).

21. Mazareanu, E. 2020. Passenger airlines in the U.S. - Statistics \& Facts, Available at: https://www.qub.ac.uk/cite2write/ harvard31.html (Accessed: $5^{\text {th }}$ September 2020).

22. Revfine. 2020. Aviation Industry: All You Need to Know About the Aviation Sector, Available at: https://www. revfine.com/aviation-industry/ (Accessed: $28^{\text {th }}$ September 2020).

23. Sarah, S. 2020. Airline Industry in Crisis Due to the COVID-19 Pandemic, Available at:https://blog.marketresearch. com/airline-industry-in-crisis-due-to-covid-19-market-researchers-assess-the-damage (Accessed: $3^{\text {rd }}$ September 2020).

24. Sobieralski, J.B. 2020. COVID-19 and airline employment: Insights from historical uncertainty shocks to the industry. Trans. Res. Interdisciplinary Perspect., 5(100123).

25. Spitz, W., O’Connor, M., Mills, R., Carroll, M. and Murray, S. 2015. Effects of airline industry changes on smalland non-hub airports. Trans. Res. Board.

26. Thomas, V. 2020. Five imperatives for airline industry survival - and revival -post COVID-19, Available at: https://www.wipro.com/blogs/thomas-vazhavelil/how-can-the-airline-industry-prepare-for-revival-post-covid-19/ (Accessed: $5^{\text {th }}$ January 2021).

27. Tracy R. and Sanjana S. 2020. U.S. airlines lay out COVID-19 damage and renew calls for aid, Available at: https:/in.reuters.com/article/us-airlines-results-usa/u-s-airlines-lay-out-covid-19-damage-and-renew-calls-for-aididUSKBN2771QB (Accessed: 28 $8^{\text {th }}$ September 2020).

28. Troy, S. 2020. The North American Airline Industry, Available at: https://www.investopedia.com/ask/answers/011215/ airline-industry-oligopoly-state.asp (Accessed: $3^{\text {rd }}$ September 2020).

29. U.S. Department of the Treasury (2020) The Treasury Department is Delivering COVID-19 Relief for All Americans, Available at: https://home.treasury.gov/policy-issues/cares (Accessed: $5^{\text {th }}$ January 2021).

30. U.S. Department of Transportation (U.S. DOT, 2020) U.S. Department of Transportation (U.S. DOT Eligible Essential Air Service (EAS) Communities. 2020 (Accessed 20.05.31).

31. U.S. Department of Transportation (U.S. DOT, 2020a) Continuation of Certain Air Service. Office of the Secretary. Final Order. Docket DOT-OST-2020-0037. https://beta.regulations.gov/document/DOT-OST-2020-0037-0047 (Accessed 20.05.31). 
